\title{
Chapter 2 \\ Estimation of Dose Rate for the Large Japanese Field Mouse (Apodemus speciosus) Distributed in the "Difficult-to-Return Zone" in Fukushima Prefecture
}

\author{
Manabu Onuma, Daiji Endoh, Hiroko Ishiniwa, and Masanori Tamaoki
}

\begin{abstract}
Following the Fukushima Daiichi Nuclear Power Plant (FNPP) accident, dose rate for Muridae species in forests of Iitate Village, Fukushima, was estimated as $3.9 \mathrm{mGy} /$ day over the first 30 days. According to the derived consideration reference levels (DCRLs) determined by the International Commission on Radiological Protection (ICRP), this dose level could be affecting reproduction of these rodents. However, information on dose rate for forest rodents after 2012 is limited. Therefore, the dose rate of forest rodents was calculated for large Japanese field mice (Apodemus speciosus) captured in the "difficult-to-return zone" in the Fukushima Prefecture from 2012 to 2016. External dose rate was calculated based on the ambient dose equivalent rate of gamma-radiation at the ground level of the trapping site. Internal dose rate was simulated using the EGS5 program based on cesium (Cs)-137 concentrations in the captured mice. Combining the external and internal doses, the total daily dose rate for the mice within the zone was estimated to be $0.201-0.547 \mathrm{mGy} /$ day. In addition, the ratio of external dose rate to total dose rate was estimated to be 61.2-95.4\%. Thus, it is concluded that the present radiation exposure of the field mice distributed in the trapping site did not affect their reproduction. However, it must be noticed that total dose rate exceeding $0.1 \mathrm{mGy} /$ day, which offers very low
\end{abstract}

\footnotetext{
M. Onuma $(\square)$

Ecological Risk Assessment and Control Section, Center for Environmental Biology and Ecosystem Studies, National Institute for Environmental Studies, Tsukuba, Japan e-mail: monuma@nies.go.jp

D. Endoh

Department of Radiation Biology, School of Veterinary Medicine, Rakuno Gakuen

University, Ebetsu, Japan

H. Ishiniwa

Institute of Environmental Radioactivity, Fukushima University,

Fukushima City, Fukushima, Japan

M. Tamaoki

Fukushima Branch, National Institute for Environmental Studies, Miharu Town, Tamura County, Fukushima, Japan
} 
probability of the occurrence of certain effects according to the DCRLs determined by ICRP, is still present in most of the zone (September 2018, Nuclear Regulation Authority, Japan). Thus, various indexes should be applied to evaluate the exposure effects on the field mice in this zone.

Keywords Large Japanese field mouse - Apodemus speciosus · Does rate · EGS5 · Cs-137

\subsection{Introduction}

The Great East Japan Earthquake occurred on March 11, 2011, 14:46 JST, with its epicenter at N38.1, E142.9 (130 km ESE off Oshika Peninsula) and a depth of $24 \mathrm{~km}$ [1]. As an aftermath of the earthquake, the coastal area of the main island, Honshu, was affected by tsunami, which resulted in loss of power supply at Fukushima Daiichi Nuclear Power Plant (FNPP). After that, reactors were damaged and meltdown occurred. Eventually, substantial amounts of radioactive materials were released into the surrounding environment. The total amount of radioactive materials released into the environment was estimated by several organizations such as the Nuclear and Industrial Safety Agency (NISA), the Nuclear Safety Commission (NSC) and Tokyo Electric Power Co. (TEPCO) [2-6]. The estimated values of iodine-131 $\left({ }^{131} \mathrm{I}\right)$ ranged between 1.2 and $5.0 \times 10^{-17} \mathrm{~Bq}$. The value of cesium-137 $\left({ }^{137} \mathrm{Cs}\right)$ was calculated to be between 8.2 and $15.0 \times 10^{-15} \mathrm{~Bq}$. The released radioactive materials formed radioactive plume, some parts of which moved into the inland, mainly Fukushima Prefecture. Radioactive materials were dissolved in rainwater contaminated soil. For example, ${ }^{131} \mathrm{I}(\mathrm{T} 1 / 2=8$ days, $71-28 \mathrm{kBq} / \mathrm{kg}),{ }^{137} \mathrm{Cs}$ $(\mathrm{T} 1 / 2=30.0$ years, $10-43 \mathrm{kBq} / \mathrm{kg})$, and ${ }^{134} \mathrm{Cs}(\mathrm{T} 1 / 2=2.06$ years, $8.5-42 \mathrm{kBq} / \mathrm{kg})$ were detected in $5 \mathrm{~cm}$ surface of soil collected from five locations of Iitate Village located 25-45 km northwest of FNNP, in March 2011 [7]. During the early phase following the accident, radioactive I was the main contaminant of the ground surface. Thereafter, ${ }^{137} \mathrm{Cs}$ became the main contaminant because of a longer half-life. ${ }^{137} \mathrm{Cs}$ decays by emitting $\beta$-particles and both Cs-137 and its metastable nuclear isomer barium-137m $\left({ }^{137 \mathrm{~m}} \mathrm{Ba}\right)$ emits $\gamma$-rays [8]. In addition, ${ }^{137} \mathrm{Cs}$ binds to clay firmly and the clay-bound ${ }^{137} \mathrm{Cs}$ has low mobility $[9,10]$. Therefore, radiation from ${ }^{137} \mathrm{Cs}$ could affect biological organisms due to long-term exposure to the contaminated environment.

The International Commission on Radiological Protection (ICRP) has recommended some organisms called reference animals and plants for environmental protection with regard to radiation [11]. Deer (family Cervidae), rat (family Muridae), duck (family Anatidae), frog (family Ranidae), bee (family Apidea), earthworm (family Lumbricidae), pine tree (family Pinacea) and wild grass (family Poaceae) are designated as reference animals and plants for the terrestrial environment. Rat (family Muridae) offers most information on radiation exposure than any other reference animals because laboratory rats and laboratory mice have been used for laboratory 
experiments in various kinds of researches, including radiation biology. Following the FNPP accident, the dose rate for rodents in the forest in Fukushima Prefecture was reported as $3.9 \mathrm{mGy} /$ day over the first 30 days [12]. According to the derived consideration reference levels (DCRLs) determined by ICRP, this dose level could be affecting reproduction, due to reduced fertility in male and female of Muridae species. However, a major portion of the radiation source changed from ${ }^{131} \mathrm{I}$ to mainly ${ }^{137} \mathrm{Cs}$ because of the decay of radioactivity, thus, it became necessary to evaluate radionuclides influence on the reproduction of Muridae species in Fukushima.

\subsection{Materials and Methods}

\subsubsection{Animals}

The Large Japanese field mouse (Apodemus speciosus) (Fig. 2.1), hereafter called as the field mouse, was selected as the target species. This species belongs to family Muridae and is a common rodent endemic to Japan. Thus, the species fulfills the criteria of reference animlas specified by ICRP and mice exposed and nonexposed to ${ }^{137} \mathrm{Cs}$ are easily obtained owing to its large distribution area in Japan.

The general information of the field mouse is as described below [13]. The ranges of their external measurements are as follows: head and body lengths, 80-140 mm; tail length, 70-130 mm; hindfoot length (not including claw), 22-28 mm; and body weight, 20-60 g. The species inhibits in Hokkaido, Honshu, Kyushu and islands larger than $10 \mathrm{~km}^{2}$. The habitats of the species are forests, plantations, riverside fields with dense grass, paddy fields and cultivated fields. Their diet consists of root and stems of herbaceous plants, nuts, berries and small insects. The breeding season varies geographically, from April to September in Sapporo City (Hokkaido), from March to April and September to November in Kyoto Prefecture (Honshu), and from October to March in Nagasaki Prefecture (Kyushu). The gestation period is 19-26 days under laboratory condition. The average litter size is 4.0-6.2 in the wild. The reported maximum life span in the wild is estimated to be 15 months in Hokkaido and 26 months in Honshu based on live trapping.

Fig. 2.1 The large Japanese field mouse (Apodemus speciosus)

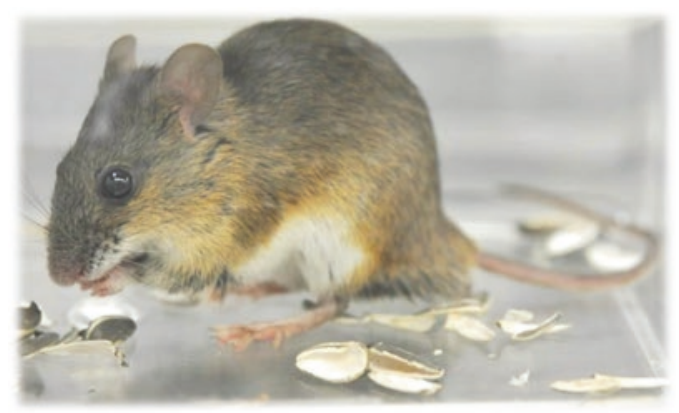


Three chromosome types are observed in these species, $2 \mathrm{n}=46$ type is distributed in Western Japan, and $2 \mathrm{n}=48$ is distributed in Eastern Japan. The hybrid type $2 n=47$ occurs on boundary of both types and is the so-called KurobeHamamatsu Line.

\subsubsection{External Dose Rate}

External dose rate was calculated from daily external dose rate based on the ambient dose equivalent rate of gamma-radiation at ground level of the trapping site.

\subsubsection{Characteristic of Trapping Site}

The trapping site (latitude, $37^{\circ} 36^{\prime} 02^{\prime \prime}$; longitude, $140^{\circ} 45^{\prime} 07^{\prime \prime} \mathrm{E}$; altitude, $578 \mathrm{~m}$ ) was located northwest of FNPP in Fukushima Prefecture. The vegetation at the site is mixed coniferous and broadleaf forest. The site was within the "difficult-to-return zone" (hereafter the DR zone). The ambient dose equivalent rate was measured at randomly chosen spots of the trapping site. The number of the measurement spots was four in 2012 and five from 2013 to 2016.

The ambient dose rate of gamma-radiation at ground level were determined using a portable environmental gamma survey meter (NHE20CY3-131By-S, Fuji Electric Co., Ltd., Tokyo, Japan) which is in full compliance with JIS Z 4333 (2006) (the conversion factor of ambient dose equivalent, $H *(10)$ for $662 \mathrm{keV} \gamma$-photons from ${ }^{137} \mathrm{Cs}$ is $\left.1.2(\mathrm{~Sv} / \mathrm{Gy})\right)$.

\subsubsection{Calculation of External Dose Rate}

Being the radiation converting factor of $\gamma$-ray 1.0 , the daily external dose rate based on the ambient dose equivalent rate was calculated using the following formula:

Daily external dose rate $(\mathrm{mGy} /$ day $)=($ Ambient dose equivalent rate of trapping site $(\mu \mathrm{Sv} / \mathrm{h}) / 1.2)$ x $24 \mathrm{hrs} / 1$ (radiation weighting factor of $\gamma$-ray)/1000

\subsubsection{Internal Dose Rate}

The daily internal dose rate based on ${ }^{137} \mathrm{Cs}$ concentration of the field mouse body was calculated using Monte Carlo electron-photon transport code EGS5 [14]. 


\subsubsection{Trapping of the Field Mice}

Trapping of the field mice was conducted by Sherman-type live traps baited with sunflower seeds. The traps were set from August to November 2012, from July to October 2013, from June to August 2014, in August 2015, and from August to September 2016. The traps were observed the following day and the trapped field mice were euthanized using $\mathrm{CO}_{2}$ asphyxiation.

The field mice were handled in accordance with the guidelines for studying wild mammals of the Mammal Society of Japan [15] and the rules of the National Institute for Environmental Studies for analysis and experimentation with environmental samples contaminated with radioactive materials. The permission for trapping the field mice was obtained from the Ministry of the Environment, Ministry of Agriculture, Forestry and Fisheries and Fukushima Prefectural Office.

\subsubsection{Measurement of ${ }^{137} \mathrm{Cs}$ Concentrations in the Field Mice}

The age of the euthanized field mice was determined based on tooth wearing [16]. The field mice having tooth wear stage 4 or above $(>5$ month in age; $>23.3 \mathrm{~g}$ in female; $>27.0 \mathrm{~g}$ in male) were used to measure ${ }^{137} \mathrm{Cs}$ concentrations. The head and internal organs were removed from the body and the processed bodies were stored at $-20{ }^{\circ} \mathrm{C}$ until the next processing. The processed body parts consisting of bones, muscles and fur skin, were minced individually using a food processer. These minced body parts were mixed well and then transferred to a polystyrene container (U8 container). High-purity germanium (HpGe) detectors (GMX45P4-76, ORTEC, TN, or GCW7023, CAMBERRA industries Inc., TN) calibrated by a standard source (MX033U8PP, the Japan Radioisotope Association) were used to measure ${ }^{137}$ Cs activity in each minced body. Gamma Studio (SEIKO EG\&G CO., LTD., Tokyo, Japan) and Spectrum Explorer (CAMBERRA) software were used to analyze the $\gamma$-ray spectra. Cs-137 radioactivity levels of sampling date were adjusted based on radioactive decay.

\subsubsection{Estimation of Radiation Dose by Intra-body ${ }^{137} \mathrm{Cs}$}

Absorbed dose due to internal exposure inside the field mice that ingested ${ }^{137} \mathrm{Cs}$ was calculated using the Monte Carlo electron-photon transport code EGS5. The energy distribution and energy spectrum of $\beta$-particles and $\gamma$-photons of ${ }^{137} \mathrm{Cs}$ were written in the EGS5 user code based on ICRP Publication 107 [17]. The shape of the field mouse body was regarded as a cylinder. The size of the cylinder was decided based on the average of external measurements on five males and five females (a diameter of $20 \mathrm{~mm}$ and a height of $122 \mathrm{~mm}$ in male and a diameter of $17 \mathrm{~mm}$ and a height of $104 \mathrm{~mm}$ in female). Whole-body dose of the field mice were calculated from energy transfer to the cylinders assuming mice body. Energy transfer of $\beta$-particles or $\gamma$-photons to the tissues was calculated by simulating the 
reaction of ${ }^{137} \mathrm{Cs}$ randomly distributed in the cylinder corresponding to the whole body, from which $\beta$-particles or $\gamma$-photons were emitted in random directions.

EGS 5 assumes a body-equivalent substance, which composed of the same atoms and having the same density as the body tissue. EGS5 simulates the interaction with the body-equivalent substance and the $\beta$-particles or $\gamma$-photons at the atomic level. For all simulated interactions, EGS 5 calculated the energy transferred to the bodyequivalent substances. EGS 5 calculates the energy $(\mathrm{J})$ transferred to substances from the $\beta$-particles and $\gamma$-photons per unit volume by summing energy transferred to the body-equivalent substance within the unit volume $\left(\mathrm{mm}^{3}\right)$. We calculated the energy transferred to the body-equivalent substance within the unit mass $(\mathrm{J} / \mathrm{kg})$ by dividing the energy transferred to the body-equivalent substance within the unit volume $\left(\mathrm{J} / \mathrm{mm}^{3}\right)$ by the density $\left(\mathrm{kg} / \mathrm{mm}^{3}\right)$ of the body-equivalent substance. We used the energy absorbed per unit mass $(\mathrm{J} / \mathrm{kg})$ as radiation dose (Gy) in the EGS5-simulation.

\subsubsection{Total Dose Rate}

Total dose rate was represented as the sum of the average of external dose rate and the average of internal dose rate in each year.

\subsection{Results}

\subsubsection{External Dose Rate}

The temporal change of the ambient dose equivalent rate of gamma-radiation at ground level of the equivalent trapping site during the study period from 2012 to 2016 is shown in Fig. 2.2. The highest average ambient equivalent dose rate, $16.7 \pm$ $4.4 \mu \mathrm{Sv} / \mathrm{h}$, was observed in 2012 . Then, the ambient dose equivalent rate gradually decreased over the study period.

Figure 2.3 shows the temporal change of external dose rate from 2012 to 2016. The highest average external dose rate, $0.335 \pm 0.076 \mathrm{mGy} /$ day was observed in 2012. The average of the external dose rate decreased gradually.

\subsubsection{Internal Dose Rate}

Table 2.1 displays the number of the field mice used to measure ${ }^{137} \mathrm{Cs}$ concentrations in this study. In total, 91 mice (male, 56; female, 35) were used. Cs-137 concentration in the field mice during the study period from 2012 to 2016 is shown in Fig. 2.4. 


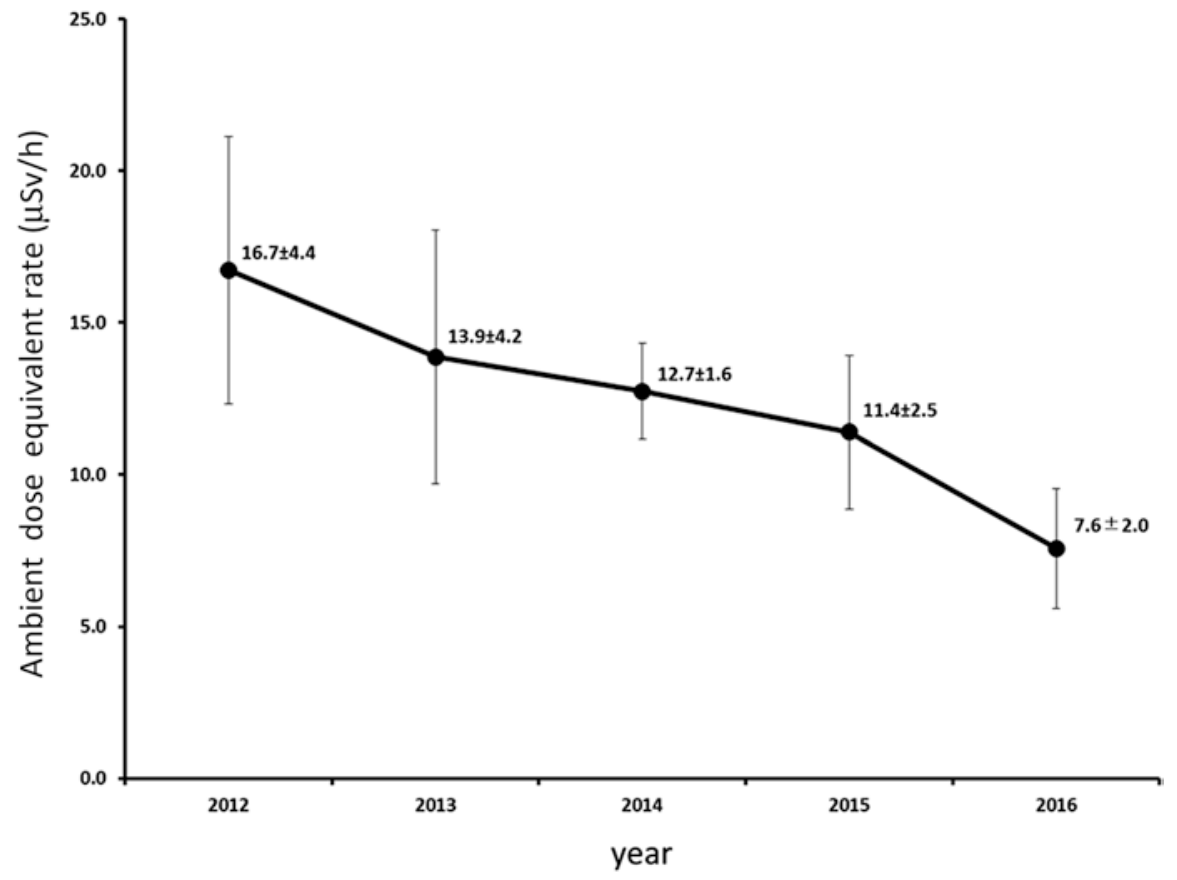

Fig. 2.2 The temporal change of the ambient dose equivalent rate of gamma-radiation at ground level of the trapping site

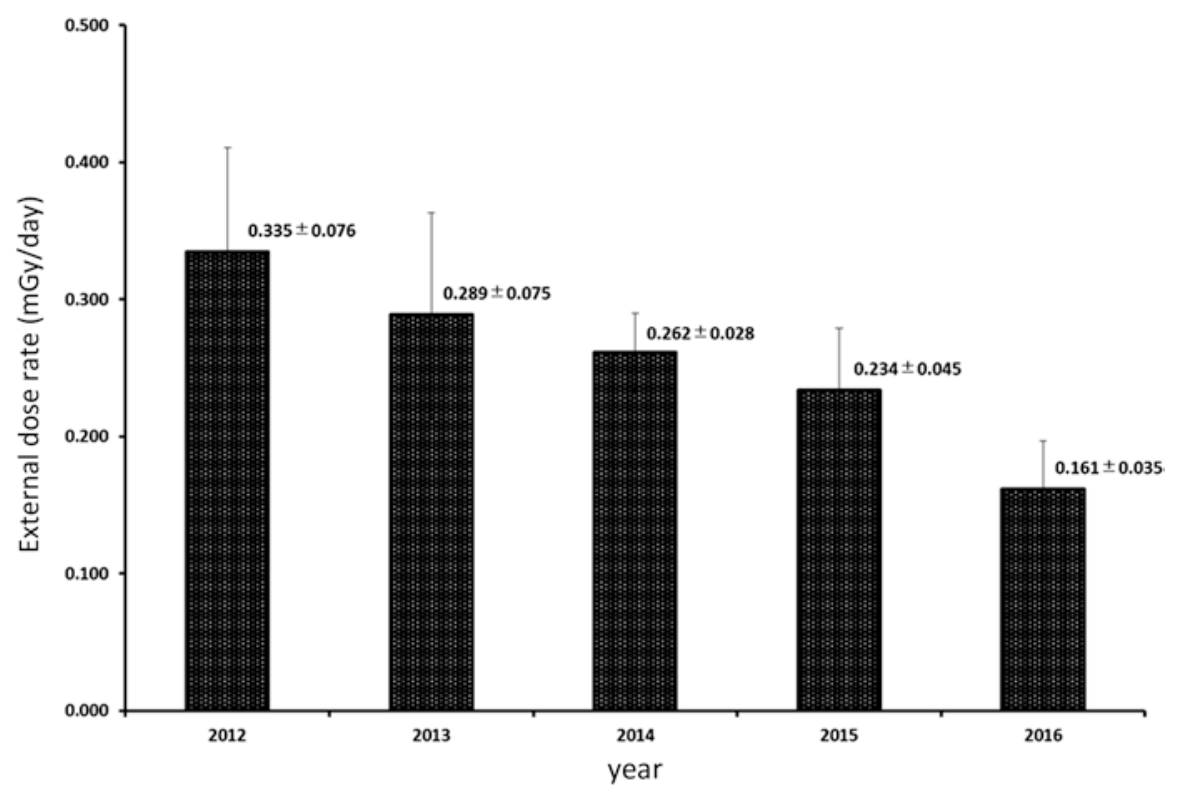

Fig. 2.3 The temporal change of external dose rate based on the ambient dose equivalent rate of gamma-radiation at ground level of the trapping site 
Table 2.1 The number of the large Japanese field mouse (Apodemus speciosus) used to measure ${ }^{137} \mathrm{Cs}$ concentrations in the present study

\begin{tabular}{|c|c|c|c|c|}
\hline \multicolumn{2}{|c|}{ Trapping time } & \multicolumn{3}{|c|}{ Number } \\
\hline Year & Month & Male & Female & Total in year \\
\hline 2012 & Aug.-Nov. & 15 & 12 & 27 \\
\hline 2013 & Jul.-Oct. & 13 & 6 & 19 \\
\hline 2014 & Jun.-Aug. & 10 & 6 & 16 \\
\hline 2015 & Aug. & 8 & 3 & 11 \\
\hline \multirow[t]{2}{*}{2016} & Aug.-Sep. & 10 & 8 & 18 \\
\hline & Total & 56 & 35 & 91 \\
\hline
\end{tabular}

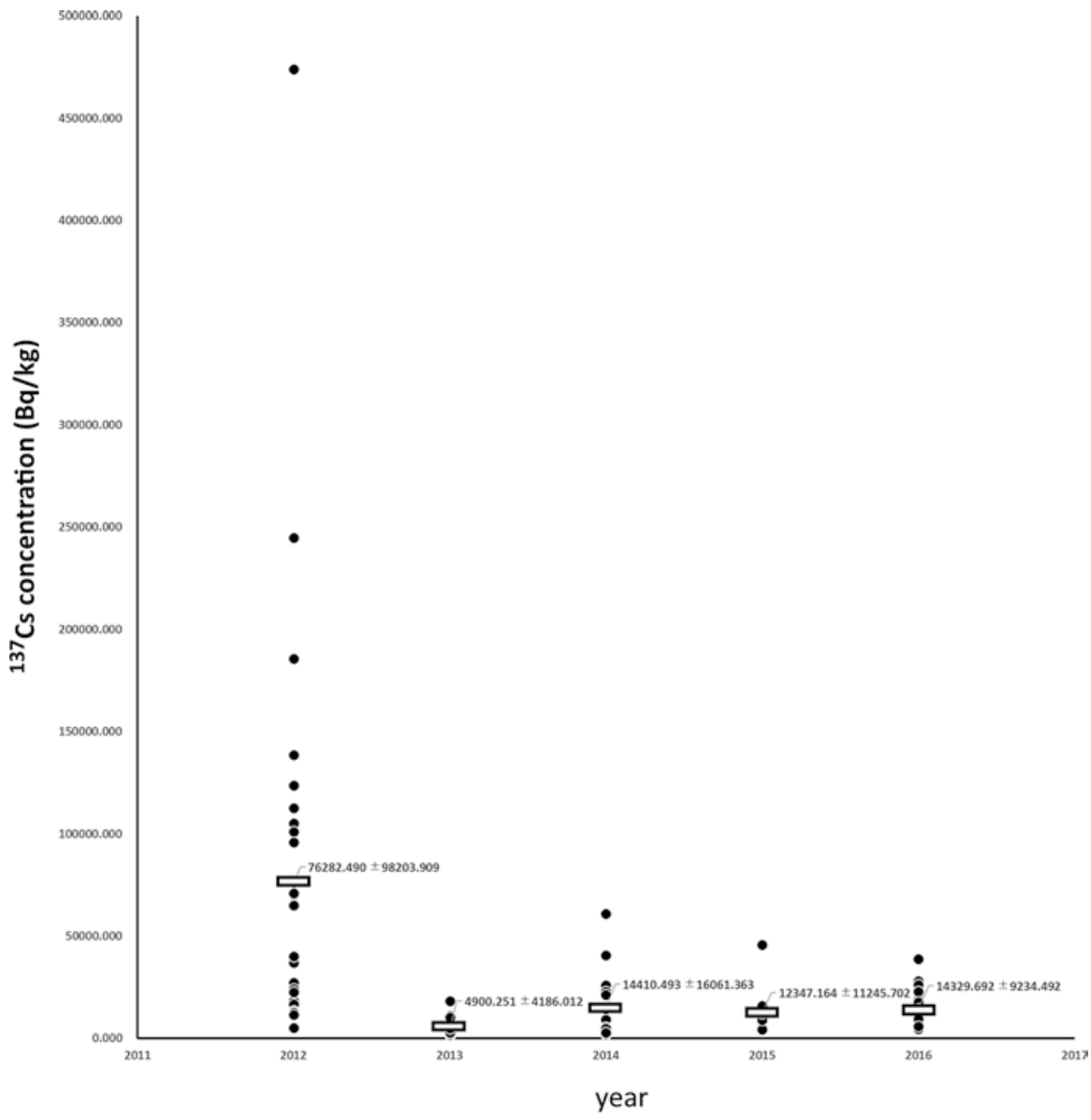

Fig. 2.4 ${ }^{137} \mathrm{Cs}$ concentration in the large Japanese field mice (Apodemus speciosus) during the study period from 2012 to 2016 . 


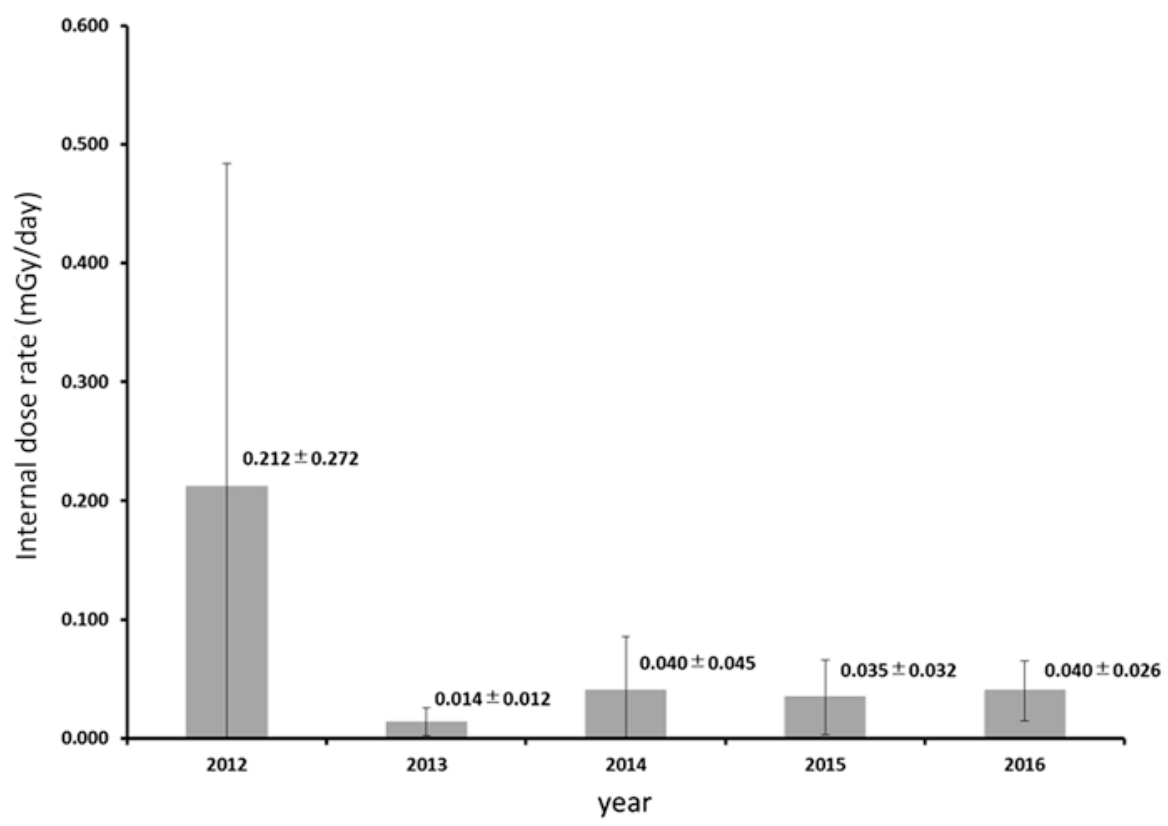

Fig. 2.5 The temporal change of daily internal dose rate based on ${ }^{137} \mathrm{Cs}$ concentrations in the large Japanese field mice body

The highest concentration, 474,076.1 Bq/kg, was observed in the female mice in 2012. Then, the concentration was indicated at less than $100,000 \mathrm{~Bq} / \mathrm{kg}$ after 2013.

Figure 2.5 shows the temporal change of daily internal dose rate from 2012 to 2016. The average of the daily internal dose rate decreased sharply from $0.212 \pm$ 0.272 to $0.014 \pm 0.012 \mathrm{mGy} /$ day between 2012 and 2013. Then, the value indicated approximately $0.040 \mathrm{mGy} /$ day after 2014 .

\subsubsection{Total Dose Rate}

The temporal change of the total dose rate of the trapping site during the study period from 2012 to 2016 is shown in Fig. 2.6. From 2012 to 2013, total dose rate decreased sharply from 0.547 to $0.303 \mathrm{mGy} /$ day and then the value gradually decreased. The ratio of external dose rate to total dose rate was calculated to be $61.2 \%, 95.4 \%, 86.7 \%, 87.0 \%$ and $80.1 \%$ in 2012, 2013, 2014, 2015 and 2016, respectively (Fig. 2.7). Thus, main exposure was attributed to the external exposure during the study period. 


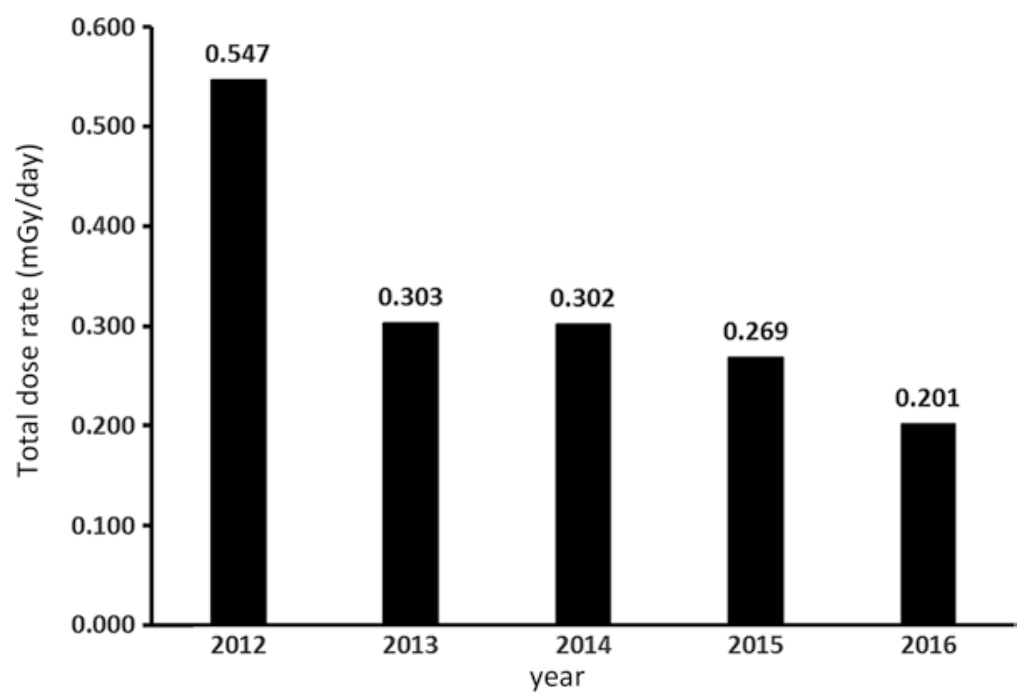

Fig. 2.6 The temporal change of total dose rate (the sum of the average of external dose rate and the average of internal dose rate)

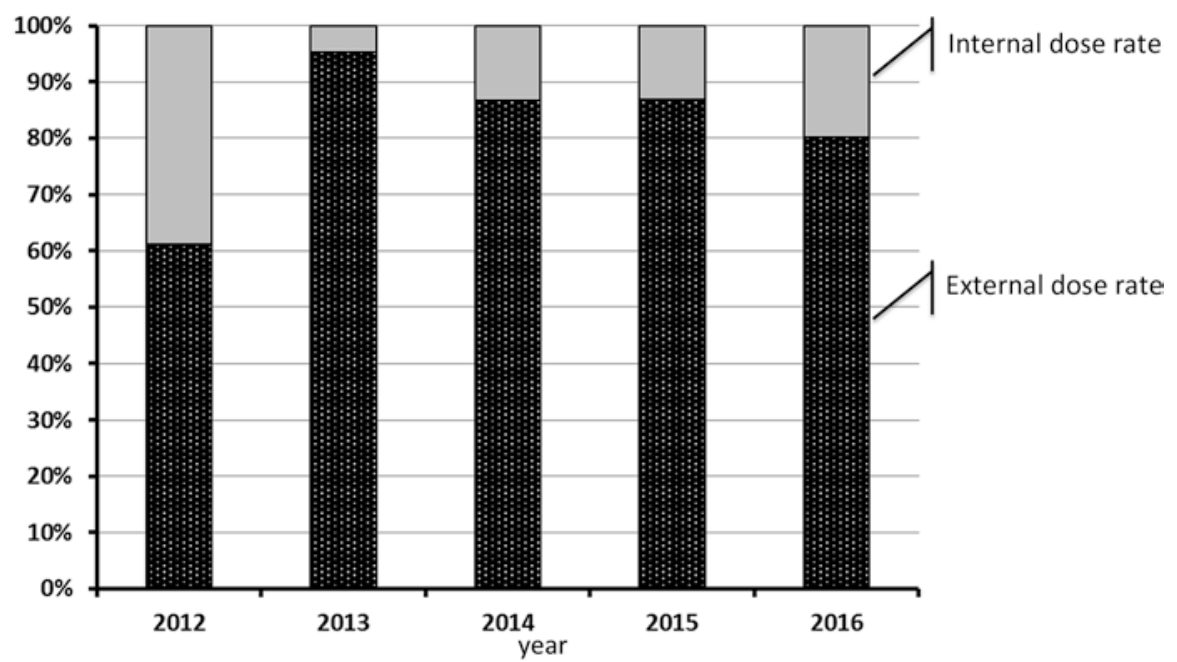

Fig. 2.7 The temporal change in the ratio of external dose rate and internal dose rate. The dose rate was mainly caused by the external dose rate during study period 


\subsection{Discussion}

The purpose of this study was to determine whether the dose rate after 2012 caused reduced fertility in male and female field mice distributed in the DR zone. The external dose rate was calculated based on the ambient dose equivalent rate at ground level at the trapping sites. The internal dose rate was simulated using EGS5 based on ${ }^{137} \mathrm{Cs}$ concentrations in the captured field mice. Total dose rate (sum of external and internal dose rate) for the field mice within the DR zone was estimated to be $0.201-0.547 \mathrm{mGy} /$ day.

According to the DCRLs determined by ICRP, exposure exceeding $1.0 \mathrm{mGy} /$ day could reduce fertility in male and female field mice. Thus, it is concluded that the present dose rate of the field mice distributed in the trapping sites was less than the dose rate that reduces fertility. The result of the present study was supported by the report on male field mice reproductive researches conducted in the same trapping site [18]. No significant increase in the apoptotic cell frequencies nor the frequencies of morphologically abnormal sperm in the field mice captured in the DR zone (ambient dose equivalent rate ranging from 12.7 to $13.9 \mu \mathrm{Sv} / \mathrm{h}$ ) was observed as compared to the results of two control sites, Aomori Prefecture and Toyama Prefecture in 2013 and 2014. The resultant median values of the apoptotic cell frequency was 5.5-7.7 cells $/ \mathrm{mm}^{2}$ of cross section area in Fukushima, 8.0-9.2 in Aomori and 8.3-9.1 in Toyama. The results of the frequencies of morphologically abnormal sperm in 100 randomly selected spermatozoa showed that the abnormality was mainly observed on the midpiece of the sperm, with the median values of the frequencies being 12-18\% in Fukushima, 13-19\% in Aomori and 15-17\% in Toyama. The statistical analysis of the frequency of apoptotic cells and that of morphologically abnormal sperm suggested no significant difference among the locations. It is reported that enhanced spermatogenesis was thought to have occurred in the field mice distributed in Tanashio $(21 \mu \mathrm{Gy} /$ day $)$, Murohara (304-365 $\mu \mathrm{Gy} /$ day) and Akogi (407-447 $\mu \mathrm{Gy} /$ day). The number of spermatogenic cells and proliferating cell nuclear antigen-positive cells per seminiferous tubule of the Akogi group was significantly higher than that in the Tanashio and Murohara groups. In addition, TUNEL-positive apoptotic cells tended to be detected at the lower level in the Murohara and Akogi groups compared to the Tanashio group where radiocontamination of the least among the three places [19].

The result of the present study suggested that the present dose rate of the field mice distributed in the trapping site does not affect the reproduction. However, it is difficult to generalize the result across the entire DR zone because levels of contamination by radioactive substances vary from location to location within the DR zone. The difference in levels of contamination may affect not only the external dose rate but also the internal dose rate through foraging activity. Therefore, further study, particularly on apoptotic cell frequencies and the frequencies of morphologically abnormal sperm, is required in heavily contaminated areas to compare the reported data. In addition, it is necessary to evaluate female reproductive organs, 
Table 2.2 Potential biological effects by deferent level of radiation for Muridae species (ICRP 2018 [17])

\begin{tabular}{|c|c|}
\hline Dose rate (mGy/day) & Effects \\
\hline$>1000$ & Mortality from haemopoietic syndrome in adults. \\
\hline 100-1000 & Reduction in lifespan due to various causes. \\
\hline 10-100 & Increased morbidity. Possible reduced lifespan. Reduced reproductive success. \\
\hline 1-10 & Potential for reduced reproductive success due to reduced fertility in males and females. \\
\hline $0.1-1$ & Derived consideration reference level for Muridae. \\
\hline $0.01-0.1$ & No observed effects. \\
\hline$<0.01$ & Natural background. \\
\hline
\end{tabular}

particularly the ovary, to gain an understanding of the actual situation of reproduction of the field mouse under the exposure. Furthermore, the effect of $\beta$-particles should be included to increase estimation accuracy of the external dose rate because the body of the field mouse is in contact with the contaminated ground in most of the time due to their activity pattern. It must be noticed that dose rate exceeding $0.1 \mathrm{mGy} /$ day, which is mainly attributed to external dose rate is still prevalent in most of the DR zone. According to the DCRLs determined by ICRP, there is a very low probability of certain effects occurring under dose rate exceeding $0.1 \mathrm{mGy} / \mathrm{day}$ (Table 2.2) [11]. Thus, various indexes should be applied to evaluate the exposure effects on the species. In fact, chromosomal aberrations in the splenic lymphocytes of field mice captured near FNPP were reported [20]. Frequencies of translocations and dicentrics per cell (\%) of the field mice distribution in "the heavily contaminated area (ambient dose equivalent rate $=80.0 \mu \mathrm{Sv} / \mathrm{h}$ )" were significantly higher than that of the control area (ambient dose rate was $0.1 \mu \mathrm{Sv} / \mathrm{h}$ ), slightly contaminated area (ambient dose equivalent rate ranging from 0.3 to $0.4 \mu \mathrm{Sv} / \mathrm{h}$ ), and moderately contaminated area (ambient dose equivalent rate ranging from 7.5 to $30.7 \mu \mathrm{Sv} / \mathrm{h}$ ). Translocations and dicentrics were mainly observed in chromosome 2 , potentially resulting from the presence of vulnerable sites to cellular stress in chromosome 2. These results, increased chromosomal aberrations, suggest that the present dose rate could affect the genome sequence of the species distributed in the DR zone. Investigation of the change of the mutation rate in germ cells is the first priority to evaluate the effect of the present dose rate on the field mouse population.

Acknowledgments We would like to thank Professor Hirayama for preparing the EGS5-code for estimating the internal exposure dose by ${ }^{137} \mathrm{Cs}$. And thanks to Dr. Tsukasa Okano for the cooperation of the research. 


\section{References}

1. Japan Meteorological Agency (2011) The 2011 Great East Japan earthquake. -Portal- http:// www.jma.go.jp/jma/en/2011_Earthquake/2011_Earthquake.html. Accessed 28 Mar 2018

2. Nuclear and Industrial Safety Agency (2011) Discharge of radioactive materials to the environment (chapter VI). Report of Japanese government to the IAEA ministerial conference on nuclear safety

3. Hoshi H, Ogino M, Kawabe R, et al (2011) Computational analysis on accident progression of Fukushima Dai-ichi NPS. PSAM topical conference in Tokyo, Japan

4. Chino M, Nakayama H, Nagai $\mathrm{H}$ et al (2011) Preliminary estimation of release amounts of ${ }^{131} \mathrm{I}$ and ${ }^{137} \mathrm{Cs}$ accidentally discharged from the Fukushima Daiichi Nuclear Power Plant into the atmosphere. J Nucl Sci Technol 48:1129-1134

5. Terada H, Tatata G, Nagai H (2012) Atmospheric discharge and dispersion of radionuclides during the Fukushima Dai-ichi Nuclear Power Plant accident. Part II: verification of the source term and analysis of regional-scale atmospheric dispersion. J Environ Radioact 112:141-154

6. Sugimoto J (2014) Accident of Fukushima Daiichi nuclear power plant: sequences, fission products released, lessons learned. In: Takahashi S (ed) Radiation monitoring and dose estimation of the Fukushima nuclear accident. Springer, Tokyo

7. Imanaka T, Endo S, Sugai M et al (2012) Early radiation survey of Iitate village, which was heavily contaminated by the Fukushima Daiichi accident, conducted on 28 and 29 March 2011. Health Phys 102:680-686

8. National Center for Biotechnology Information (n.d.) PubChem compound database; $\mathrm{CID}=5486527$. https://pubchem.ncbi.nlm.nih.gov/compound/5486527. Accessed $18 \mathrm{Mar}$ 2018

9. Matsuda N, Mikami S, Shimoura S et al (2015) Depth profiles of radioactive cesium in soil using a scraper plate over a wide area surrounding the Fukushima Dai-ichi Nuclear Power Plant, Japan. J Environ Radioact 139:427-434

10. Takahashi J, Tamura K, Suda T et al (2015) Vertical distribution and temporal changes of 137Cs in soil profiles under various land uses after the Fukushima Dai-ichi Nuclear Power Plant accident. J Environ Radioact 139:351-361

11. ICRP (2008) Environmental protection: the concept and use of reference animals and plants, ICRP publication 108. Ann ICRP 38(4-6):1-242. (August-December 2008)

12. Garnier-Laplace J, Beaugelin-Seiller K, Hinton TG (2011) Fukushima wildlife dose reconstruction signals ecological consequences. Environ Sci Technol 45:5077-5078

13. Ohdachi SD, Ishibashi Y, Iwasa MA et al (2009) The wild mammals of Japan. Shoukadoh Book Sellers and the Mammal Society of Japan, Kyoto. $511 \mathrm{pp}$

14. Hirayam H, Namito Y, Bielajew AF, et al (2005) The EGS5 code system. KEK Report 20058, SLAC-R-730. High Energy Accelerator Research Organization (KEK), Stanford Linear Accelerator Center (SLAC). 2005, National Technical Information Service, U.S. Department of Commerce, Springfield, VA, USA

15. Committee of Reviewing Taxon Names and Specimen Collections, the Mammal Society of Japan (2009) Guideline for using wild mammals. Mamm Sci 49:303-319. (in Japanese)

16. Hikida T, Murakami O (1980) Age determination of the Japanese wood mouse, Apodemus speciosus. Nihon Seitai Gakkaishi 30:109-116. in Japanese

17. ICRP (2008) Nuclear decay data for dosimetric calculations. ICRP publication 107. Ann ICRP 38(3), Supplement p62 
18. Okano T, Ishiniwa H, Onuma $\mathrm{M}$ et al (2016) Effects of environmental radiation on testes and spermatogenesis in wild large Japanese field mice (Apodemus speciosus) from Fukushima. Sci Rep. 23 6:23601

19. Takino S, Yamashiro H, Sugano Y et al (2017) Analysis of the effect of chronic and low-dose radiation exposure on spermatogenic cells of male Large Japanese Field Mice (Apodemus speciosus) after the Fukushima Daiichi Nuclear Power Plant Accident. Radiat Res 187:161-168

20. Kawagoshi T, Shiomi N, Takahashi H et al (2017) Chromosomal aberrations in Large Japanese Field Mice (Apodemus speciosus) captured near Fukushima Dai-ichi Nuclear Power Plant. Environ Sci Technol 51:4632-4641

Open Access This chapter is licensed under the terms of the Creative Commons Attribution 4.0 International License (http://creativecommons.org/licenses/by/4.0/), which permits use, sharing, adaptation, distribution and reproduction in any medium or format, as long as you give appropriate credit to the original author(s) and the source, provide a link to the Creative Commons license and indicate if changes were made.

The images or other third party material in this chapter are included in the chapter's Creative Commons license, unless indicated otherwise in a credit line to the material. If material is not included in the chapter's Creative Commons license and your intended use is not permitted by statutory regulation or exceeds the permitted use, you will need to obtain permission directly from the copyright holder.

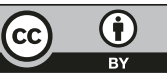

